ISSN 0258-7122

Bangladesh J. Agril. Res. 35(3) : 515-523, September 2010

\title{
NITROGEN UPTAKE AND PROTEIN YIELD IN LENTIL AS INFLUENCED BY SEED COLLECTION FROM DIFFERENT PARTS OF PLANTS
}

\author{
A. KHATUN ${ }^{1}$, M. A. H. BHUIYAN ${ }^{2}$ AND T.K. DEY ${ }^{3}$
}

\begin{abstract}
Field experiments were carried out during rabi (winter) seasons of 2004-2005 and 2005-2006 at the Bangladesh Agricultural Research Institute Farm, Gazipur to determine the effects of seeds collected from different plant parts on nitrogen content and nitrogen uptake, protein content, and protein yield of lentil. Lentil seeds were collected from different parts of lentil plants viz. i) seeds collected from upper parts $\left(\mathrm{P}_{1}\right)$, ii) seeds collected from middle parts $\left(\mathrm{P}_{2}\right)$, and iii) seeds collected from lower parts of lentil plants $\left(\mathrm{P}_{3}\right)$. Significant variation among the three test varieties of lentil was observed for nitrogen content and nitrogen uptake, and protein content where the highest concentration of nitrogen was observed in BARI Masur-4 which ultimately gave higher protein yield, while the lowest was in BARI Masur-2. Seeds collected from different plant parts had significant effect for nitrogen and protein content where $\mathrm{P}_{3}$ site recorded the highest results. BARI Masur-2 seeds collected from lower parts of lentil recorded higher $\mathrm{N}$ content and protein content but BARI Masur-4 seeds collected from lower parts or BARI Masur-3 seeds collected from middle parts gave higher $\mathrm{N}$ uptake and protein yield.
\end{abstract}

Keywords: Lentil, nitrogen uptake, protein yield.

\section{Introduction}

Seed maturation refers to morphological, physiological, and functional changes that occur from the time of fertilization to maturation of ovules that are ready for harvest (Delouche, 1973). While, Abdul-Baki and Baker (1973) defined seed development as the period between fertilization and maximum fresh weight accumulation; and seed maturation begins at the end of seed development and continues upto harvest. According to Harrington (1972), physiological maturity of seeds means attaining maximum dry weight at which nutrients are not flowing into seed from mother plant. At physiological maturity, vascular connection to the seed is broken by formation of an abscission layer which looks black to the naked eye. The seed potential may be impaired, while the seeds are still developing on the mother plant.

\footnotetext{
${ }^{1}$ Senior Scientific Officer, Planning and Evaluation Division, Bangladesh Agricultural Research Institute (BARI), Gazipur, ${ }^{2}$ Senior Scientific Officer, Soil Science Division, Bangladesh Agricultural Research Institute (BARI), Gazipur, ${ }^{3}$ Principal Scientific Officer, TCRC, Bangladesh Agricultural Research Institute (BARI), Gazipur, Bangladesh.
} 
Seed development and maturation study is important to ensure good yield associated with seed viability, vigour and field performance (Dharmalingam and Basu, 1990). If the seeds are retained on the mother plant for longer duration after physiological maturity might lead to development of hard seeds or offcolour seeds in pulse crops (Dharmalingam and Ramakrishnan, 1978).

Moisture content of harvested crop affects seed quality and hence it determines with which moisture content the crop should be threshed. Harvesting at high moisture content increases the chances of mycofloral infection on chickpea seed, while harvesting at low moisture content increases mechanical damage to seed (Yadav et al., 2005). Mahesha et al. (2001) reported that early harvested seeds of sunflower were immature and poorly developed and as such are poor storers compared to seed harvested at physiological maturity. Kumar et al. (2002) reported that seed yield and quality of paprika largely depends on the stage of maturity. As such, harvesting of seeds at right stage of maturity is most important since harvesting either at early or late stage results in lower yields with poor quality seeds. Afzal et al. (2003) found that BARI Masur-4 showed 4.13\% nitrogen, while BARI Masur-3 had 4.08\% and BARI Masur-2 had 4.53\% nitrogen. Therefore, it is necessary to identify right time for harvesting pulse crops in order to ensure seed quality. The experiment was conducted to determine the effects of seeds collected from different plant parts on nitrogen content and nitrogen uptake, protein content and protein yield of lentil.

\section{Materials and Method}

Experiments were carried out at the Research Field of the Pulse Research Centre, Bangladesh Agricultural Research Institute (BARI), Joydebpur, Gazipur, Bangladesh during the rabi (winter) seasons of 2004-2005 and 2005-06. During rabi season of 2003-04, lentil seeds of three popular varieties viz. BARI Masur2, BARI Masur-3, and BARI Masur-4 were collected from three sites of lentil plant viz. i) seeds collected from upper parts of lentil plant ( $\mathrm{P}_{1}$ parts), ii) seeds collected from middle parts of lentil plant $\left(\mathrm{P}_{2}\right.$ parts), and iii) seeds collected from lower parts of lentil plant $\left(\mathrm{P}_{3}\right.$ parts). The collected seeds were preserved in earthen pot. Before setting up the field experiment, laboratory experiment was carried out for recording seed quality data (moisture percentage, germination percentage and vigour). The experimental field was high land with drainage and irrigation facilities. The area belongs to the Agro-ecological Zone-28 (AEZ 28) under Madhupur Tract. The experimental site is situated at $24.00^{\circ}$ North Latitude and $90.26^{\circ}$ East Longitude. The area received a long-term average rainfall (2142 $\mathrm{mm})$ and average maximum monthly temperature was observed in April $\left(32.6^{\circ} \mathrm{C}\right)$ and the minimum in December $\left(11.2^{\circ} \mathrm{C}\right)$ (BARI, 2004).

Field experiments were conducted using the collected seeds in a factorial randomized complete block design. Row to row distance was $30 \mathrm{~cm}$ and plant to 
plant distance was $10 \mathrm{~cm}$. Unit plot size was $3 \mathrm{~m} \times 4 \mathrm{~m}$. Seeds were sown in 18 November 2004 and 11 November 2005, and harvested on 01 March 2005 and 25 February 2006, respectively. After harvesting, seeds of whole plot were dried to attain $10 \%$ moisture content and kept in polyethylene bag for determination of nitrogen concentration in seed. All the data were statistically analyzed using IRRISTAT package programme.

Collection and preparation of seed samples for chemical analysis: Seed samples were collected from bulk harvest. The seed samples were then oven dried at $65^{\circ} \mathrm{C}$ for 24 hours and then ground. To obtain homogenous powder, the samples were passed through a 60-mesh sieve. The samples were stored in air tight polyethylene bags for nitrogen (N) determination (Page et al., 1982).

Estimation of $\mathrm{N}$ : The $\mathrm{N}$ content in seed was determined by micro-Kjeldahl method. The seed samples ( $0.1 \mathrm{~g}$ seed) were digested with conc. $\mathrm{H}_{2} \mathrm{SO}_{4}$, hydrogen peroxide and $\mathrm{K}_{2} \mathrm{SO}_{4}$-catalyst mixture $\left(\mathrm{K}_{2} \mathrm{SO}_{4}: \mathrm{CuSO}_{4} \cdot 5 \mathrm{H}_{2} \mathrm{O}\right.$ : $\left.\mathrm{Se}=10: 1: 0.1\right)$ at $200^{\circ} \mathrm{C}$ for one and a half-hour. Nitrogen was estimated by distilling the digest with $10 \mathrm{~N} \mathrm{~N} \mathrm{~N}_{\mathrm{a}} \mathrm{OH}$ followed by titration of the distillate trapped in $\mathrm{H}_{3} \mathrm{~B}_{3}$ indicator solution with $0.01 \mathrm{~N} \mathrm{H}_{2} \mathrm{SO}_{4}$ (Page et al., 1982).

Calculation of protein content and protein yield: Protein content of lentil seed was determined by multiplying the $\mathrm{N}$ content of lentil seed with 6.25.

Nitrogen uptake and protein yield of lentil seed was computed from the following formulae-Nitrogen uptake $(\mathrm{kg} / \mathrm{ha})=\{$ Nitrogen content $(\%) \times$ seed yield (kg/ha) $\} / 100$.

Protein yield $(\mathrm{kg} / \mathrm{ha})=\{$ Protein content $(\%) \times$ seed yield $(\mathrm{kg} / \mathrm{ha}\} / 100$

Statistical analysis: The data for different characters were subjected to statistical analysis following a IRRISTAT package programme. The correlation co-efficient were done for different variables as needed.

\section{Results and Discussion}

Nitrogen content: Lentil varieties differed significantly in nitrogen content (Table 1). The highest N content was observed in BARI Masur-4, which differed from BARI Masur-2 but identical to BARI Masur-3 in both the years. Although, Shahjahan (2003) observed that lentil contained higher nitrogen content than chickpea (4.72\% in lentil and 3.75\% in chickpea), varietal differences in nitrogen content of lentil were not conspicuous e.g. BARI Masur-4 showed $4.13 \%$ nitrogen, while BARI Masur-3 had 4.08\% and BAR! Masur-2 had 4.53\% nitrogen (Afzal et al., 2003). Tomar et al. (2000) reported that among four varieties of lentil, nitrogen content ranged from 3.05\% to 3.21\%. Shahjahan 
(2003) found that lentil seeds contained 3.53-4.03\% nitrogen in six types of containers over periods. Seeds collected from different plant parts were significant on N concentration (Table 2). During both the years, seeds collected from lower parts of lentil recorded significantly higher $\mathrm{N}$ content. It accumulated about 2\% more $\mathrm{N}$ than seeds collected from upper parts of lentil plants. Interaction effect of varieties and seeds collected from different plant parts revealed that $\mathrm{V}_{1} \times \mathrm{P}_{3}$ gave the highest $\mathrm{N}$ content, and $\mathrm{V}_{1} \times \mathrm{P}_{2}$ gave the lowest $\mathrm{N}$ content (Table 3).

Nitrogen uptake: Varieties differed significantly for nitrogen uptake (Table 1). The highest $\mathrm{N}$ uptake was achieved by BARI Masur-4 in both the years that differed from other two varieties in 2004-05 but identical to other two varieties in 2005-06. Higher nitrogen uptake was associated with higher seed yield. The lowest $\mathrm{N}$ uptake was observed in BARI Masur-2. The results are in agreement with Bhuiyan (2004), who reported that varieties differed for $\mathrm{N}$ uptake in mungbean. Afzal et al. (2003) also reported similar results for nitrogen uptake in lentil. Nitrogen uptake was not significant in seeds collected from different plant parts (Table 2). Seeds collected from middle plant parts $\left(\mathrm{P}_{2}\right)$ apparently gave the highest $\mathrm{N}$ uptake which was similar to $\mathrm{P}_{1}$ and $\mathrm{P}_{3}$. Seeds collected from middle plant parts accumulated $13.8 \%$ more $\mathrm{N}$ in $2004-05$ and $15.4 \%$ more $\mathrm{N}$ in 2005-06 than the seeds collected from upper plant parts.

Interaction effects of $\mathrm{V}_{3} \times \mathrm{P}_{3}$ in 2004-05 and $\mathrm{V}_{2} \times \mathrm{P}_{2}$ in 2005-06 showed significantly higher nitrogen uptake (Table 3 ). The highest nitrogen uptake recorded for $V_{3} \times P_{3}$ in 2004-05, which was similar to $V_{2} \times P_{2}$ and by $V_{2} \times P_{2}$ in 2005-06 which was similar to $V_{1} \times P_{3}, V_{3} \times P_{1}, V_{3} \times P_{2}$ and $V_{3} \times P_{3}$.

Table 1. Effects of different lentil varieties on nitrogen content and nitrogen uptake.

\begin{tabular}{l|lll|l|l}
\hline \multirow{2}{*}{ Variety } & \multicolumn{2}{c|}{ N content (\%) } & \multicolumn{2}{c}{ Nitrogen uptake (kg/ha) } \\
\cline { 2 - 6 } & $2004-05$ & 2005-06 & 2004-05 & 2005-06 \\
\hline BARI Masur-2 $\left(\mathrm{V}_{1}\right)$ & $4.25 \mathrm{~b}$ & $4.26 \mathrm{~b}$ & $30.3 \mathrm{~b}$ & 30.9 \\
BARI Masur-3 $\left(\mathrm{V}_{2}\right)$ & $4.3 \mathrm{Oab}$ & $4.28 \mathrm{a}$ & $31.6 \mathrm{~b}$ & 34.1 \\
BARI Masur-4 $\left(\mathrm{V}_{3}\right)$ & $4.34 \mathrm{a}$ & $4.33 \mathrm{a}$ & $37.2 \mathrm{a}$ & 36.7 \\
\hline SE $( \pm)$ & 0.015 & 0.016 & 1.34 & - \\
Level of significance & $* *$ & $*$ & $*$ & $\mathrm{NS}$ \\
\hline
\end{tabular}

In a column, the figure(s) having same letter(s) are not significantly different as per DMRT.

*significant at 5\% level, **Significant at 1\% level, NS: Not significant. 
Table 2. Effects of lentil seeds collected from different plant parts on nitrogen content and nitrogen uptake.

\begin{tabular}{|c|c|c|c|c|}
\hline \multirow{2}{*}{$\begin{array}{l}\text { Seeds collected from } \\
\text { different plant parts }\end{array}$} & \multicolumn{2}{|c|}{$\mathrm{N}$ content $(\%)$} & \multicolumn{2}{|c|}{ Nitrogen uptake (kg/ha) } \\
\hline & $2004-05$ & 2005-06 & 2004-05 & 2005-06 \\
\hline Upperpart( $\left(\mathrm{P}_{1}\right)$ & $4.25 b$ & $4.25 b$ & 30.5 & 31.1 \\
\hline Middle part $\left(\mathrm{P}_{2}\right)$ & 4.29ab & $4.27 \mathrm{~b}$ & 34.7 & 35.9 \\
\hline Lower part $\left(\mathrm{P}_{3}\right)$ & $4.34 \mathrm{a}$ & $4.35 \mathrm{a}$ & 34.0 & 34.6 \\
\hline $\mathrm{SE}( \pm)$ & 0.015 & 0.016 & - & - \\
\hline Level of significance & ** & ** & NS & NS \\
\hline
\end{tabular}

In a column, the figure(s) having same letter(s) are not significantly different as per DMRT.

**significant at $1 \%$ level, NS: Not significant.

Table 3. Interaction effects of varieties and seeds collected from different plant parts on nitrogen content and nitrogen uptake.

\begin{tabular}{l|lll|l|l}
\hline \multirow{2}{*}{$\begin{array}{c}\text { Interaction } \\
(\mathrm{V} \times \mathrm{P})\end{array}$} & \multicolumn{3}{c|}{$\mathrm{N}$ content (\%) } & \multicolumn{2}{c}{ Nitrogen uptake $(\mathrm{kg} / \mathrm{ha})$} \\
\cline { 2 - 5 } & \multicolumn{2}{c}{$2004-05$} & \multicolumn{1}{c}{$2005-06$} & \multicolumn{1}{c}{$2004-05$} & \multicolumn{1}{c}{$2005-06$} \\
\hline $\mathrm{V}_{1} \times \mathrm{P}_{1}$ & $4.15 \mathrm{c}$ & $4.18 \mathrm{~cd}$ & $35 . \mathrm{bc}$ & $29.9 \mathrm{bc}$ \\
$\mathrm{V}_{1} \times \mathrm{P}_{2}$ & $4.15 \mathrm{c}$ & $4.17 \mathrm{~cd}$ & $25.5 \mathrm{~d}$ & $27.5 \mathrm{c}$ \\
$\mathrm{V}_{1} \times \mathrm{P}_{3}$ & $4.44 \mathrm{a}$ & $4.42 \mathrm{a}$ & $30.2 \mathrm{~cd}$ & $35.4 \mathrm{abc}$ \\
$\mathrm{V}_{2} \times \mathrm{P}_{1}$ & $4.25 \mathrm{~b}$ & $4.26 \mathrm{bcd}$ & $25.3 \mathrm{~d}$ & $27.4 \mathrm{c}$ \\
$\mathrm{V}_{2} \times \mathrm{P}_{2}$ & $4.39 \mathrm{a}$ & $4.30 \mathrm{abc}$ & $44.0 \mathrm{ab}$ & $43.5 \mathrm{a}$ \\
$\mathrm{V}_{2} \times \mathrm{P}_{3}$ & $4.25 \mathrm{bc}$ & $4.27 \mathrm{bcd}$ & $25.6 \mathrm{~cd}$ & $31.3 \mathrm{bc}$ \\
$\mathrm{V}_{3} \times \mathrm{P}_{1}$ & $4.34 \mathrm{ab}$ & $4.30 \mathrm{abc}$ & $31.0 \mathrm{~cd}$ & $36.1 \mathrm{abc}$ \\
$\mathrm{V}_{3} \times \mathrm{P}_{2}$ & $4.34 \mathrm{ab}$ & $4.34 \mathrm{ab}$ & $34.5 \mathrm{bcd}$ & $36.7 \mathrm{abc}$ \\
$\mathrm{V}_{3} \times \mathrm{P}_{3}$ & $4.34 \mathrm{ab}$ & $4.35 \mathrm{ab}$ & $46.1 \mathrm{a}$ & $37.2 \mathrm{ab}$ \\
$\mathrm{SE}( \pm)$ & 0.025 & 0.028 & 2.32 & 3.13 \\
\hline Level of significance & $* *$ & $* *$ & $* *$ & $*$ \\
$\mathrm{CV}(\%)$ & 1.0 & 1.1 & 12.2 & 16.0 \\
\hline
\end{tabular}

In a column, the figure(s) having same letter(s) are not significantly different as per DMRT.

*significant at 5\% level, **significant at $1 \%$ level.

Protein content: Varieties varied significantly regarding protein content in seeds (Table 4). The highest protein content in seeds was observed in BARI Masur-4, which was statistically identical to BARI Masur-3. Afzal et al. (2003) reported that BARI Masur-4 showed $25.80 \%$ protein, while BARI Masur-3 contained 
25.50\%, and BARI Masur-2 contained $28.31 \%$ protein. Seeds collected from lower plant parts had greater protein content than the seeds collected from middle and upper plant parts of lentil (Table 5). The highest protein content was recorded with seeds collected from lower parts $\left(\mathrm{P}_{3}\right)$ in both the years, which were statistically identical to BARI Masur-3 only in 2004-05. Interaction of variety and seeds collected from different plant parts was significant for protein content (Table 6). The highest protein content were found in $V_{1} \times P_{3}$, which was statistically different from all other treatments except $V_{2} \times P_{2}, V_{3} \times P_{1}, V_{3} \times P_{2}$, $\mathrm{V}_{3} \times \mathrm{P}_{3}$ in 2004-05, and $\mathrm{V}_{3} \times \mathrm{P}_{2}, \mathrm{~V}_{3} \times \mathrm{P}_{3}$ in 2005- 06 .

Protein yield: The highest protein yield in seed was observed in BARI Masur-4, which was different from BARI Masur-2 in 2004-05, but statistically identical to other two varieties in 2005-06. The protein yield was the lowest in BARI Masur2. Tomar et al. (2000) reported that among four lentil genotypes, Pant L 639 recorded significantly higher protein yield. Protein yield in seeds collected from middle part was higher than the seeds collected from upper or lower parts of lentil plants though statistically not significant (Table 5). Seeds collected from middle plant part produced higher yield of protein over seeds collected from lower or upper plant parts. Interaction effect of variety and seeds collected from different plant parts was significant on protein yield of lentil (Table 6). This might be due to dissimilar response of three varieties with seeds collected from different parts on protein yield. The highest protein yield was found in $\mathrm{V}_{3} \times \mathrm{P}_{3}$ in 2004-05 and in $\mathrm{V}_{2} \times \mathrm{P}_{2}$ in 2005-06.

Table 4. Effects of different lentil varieties on protein content and protein yield.

\begin{tabular}{l|lll|l}
\hline \multirow{2}{*}{ Variety } & \multicolumn{2}{c|}{ Protein content (\%) } & \multicolumn{2}{c}{ Protein yield (kg/ha) } \\
\cline { 2 - 5 } & 2004-05 & \multicolumn{1}{c}{ 2005-06 } & \multicolumn{1}{c}{ 2004-05 } & 2005-06 \\
\hline BARI Masur-2 $\left(\mathrm{V}_{1}\right)$ & $26.5 \mathrm{~b}$ & $26.6 \mathrm{~b}$ & $189 \mathrm{~b}$ & 192 \\
BARI Masur-3 $\left(\mathrm{V}_{2}\right)$ & $26.9 \mathrm{ab}$ & $26.8 \mathrm{ab}$ & $198 \mathrm{ab}$ & 210 \\
BARI Masur-4 $\left(\mathrm{V}_{3}\right)$ & $27 . l \mathrm{a}$ & $27.1 \mathrm{a}$ & $232 \mathrm{a}$ & 229 \\
\hline SE $( \pm)$ & 0.09 & 0.10 & 8.39 & - \\
Level of significance & $* *$ & $*$ & $* *$ & NS \\
\hline
\end{tabular}

In a column, the figure(s) having same letter(s) are not significantly different as per DMRT.

*Significant at $5 \%$ level.

**Significant at $1 \%$ level, NS: Not significant. 
Table 5. Effects of lentil seeds collected from different plant parts on protein content and protein yield.

\begin{tabular}{l|lll|l}
\hline \multirow{2}{*}{$\begin{array}{c}\text { Seeds collected from } \\
\text { different plant parts }\end{array}$} & \multicolumn{2}{c|}{ Protein content (\%) } & \multicolumn{2}{c}{ Protein yield (kg/ha) } \\
\cline { 2 - 6 } & 2004-05 & 2005-06 & 2004-05 & 2005-06 \\
\hline Upper part $\left(\mathrm{P}_{1}\right)$ & $26.5 \mathrm{~b}$ & 26.6 & 190 & 195 \\
Middle part $\left(\mathrm{P}_{2}\right)$ & $26.8 \mathrm{ab}$ & $26.7 \mathrm{~b}$ & 217 & 224 \\
Lowerpart $\left(\mathrm{P}_{3}\right)$ & $27.1 \mathrm{a}$ & $27.2 \mathrm{a}$ & 212 & 212 \\
\hline $\mathrm{SE}( \pm)$ & 0.09 & 0.10 & - & - \\
Level of significance & $* *$ & $* *$ & $\mathrm{~ns}$ & $\mathrm{~ns}$ \\
\hline
\end{tabular}

In a column, the figure(s) having same letter(s) are not significantly different as per DMRT.

**Significant at $1 \%$ level, NS: Not significant.

Table 6. Interaction effects of lentil varieties and seeds collected from different plant parts on protein content and protein yield.

\begin{tabular}{llllll}
\hline \multirow{2}{*}{$\begin{array}{c}\text { Interaction } \\
(\mathrm{V} \times \mathrm{P})\end{array}$} & \multicolumn{2}{c|}{ Protein content (\%) } & \multicolumn{2}{c}{ Protein yield (kg/ha) } \\
\cline { 2 - 5 } & \multicolumn{1}{c}{$2004-05$} & $2005-06$ & $2004-05$ & $2005-06$ \\
\hline $\mathrm{V}_{1} \times \mathrm{P}_{1}$ & $25.9 \mathrm{c}$ & $26 . \mathrm{lc}$ & $219 \mathrm{bc}$ & $187 \mathrm{c}$ \\
$\mathrm{V}_{1} \times \mathrm{P}_{2}$ & $25.9 \mathrm{c}$ & $26 . \mathrm{lc}$ & $159 \mathrm{~cd}$ & $172 \mathrm{c}$ \\
$\mathrm{V}_{1} \times \mathrm{P}_{3}$ & $27.7 \mathrm{a}$ & $27.6 \mathrm{a}$ & $189 \mathrm{~cd}$ & $217 \mathrm{~b}$ \\
$\mathrm{~V}_{2} \times \mathrm{P}_{1}$ & $26.6 \mathrm{bc}$ & $26.7 \mathrm{bc}$ & $158 \mathrm{~d}$ & $172 \mathrm{c}$ \\
$\mathrm{V}_{2} \times \mathrm{P}_{2}$ & $27.4 \mathrm{a}$ & $26.9 \mathrm{~b}$ & $275 \mathrm{ab}$ & $272 \mathrm{a}$ \\
$\mathrm{V}_{2} \times \mathrm{P}_{3}$ & $26.6 \mathrm{bc}$ & $26.7 \mathrm{bc}$ & $160 \mathrm{~cd}$ & $188 \mathrm{c}$ \\
$\mathrm{V}_{3} \times \mathrm{P}_{1}$ & $27.1 \mathrm{~b}$ & $26.9 \mathrm{~b}$ & $194 \mathrm{~cd}$ & $226 \mathrm{~b}$ \\
$\mathrm{~V}_{3} \times \mathrm{P}_{2}$ & $27.1 \mathrm{~b}$ & $27.1 \mathrm{ab}$ & $216 \mathrm{bcd}$ & $229 \mathrm{~b}$ \\
$\mathrm{~V}_{3} \times \mathrm{P}_{3}$ & $27 . l a b$ & $27.2 \mathrm{ab}$ & $288 \mathrm{a}$ & $232 \mathrm{~b}$ \\
\hline $\mathrm{SE}( \pm)$ & 0.16 & 0.17 & 14.53 & 18.91 \\
Level of significance & $* *$ & & $* *$ & $*$ \\
$\mathrm{CV}(\%)$ & 1.0 & 1.1 & 12.2 & 15.6 \\
\hline
\end{tabular}

In a column, the figure(s) having same letter(s) are not significantly different as per DMRT.

*significant at $5 \%$ level, **significant at $1 \%$ level.

Correlation: Correlation matrix among the plant characters of lentil is shown in Table 7. A positive and significant correlation was observed between seed yield and $\mathrm{N}$ uptake and protein yield, and $\mathrm{N}$ uptake and protein yield (2004-05 and 
2005-06). Uptake by plant showed highly significant positive correlation with seed yield (Dwivedi et al., 1990). Grain yield of chickpea was positively correlated with protein yield (Quader, 1990). Bhuiyan (2004) also found a positive and significant correlation between seed yield and $\mathrm{N}$ uptake and protein yield in mungbean. In another study, Hossain et al. (2004) found that nitrogen uptake in mungbean showed positive relationship with increasing seedling mass $\left(\mathrm{R}^{2}=0.39\right)$.

Table 7. Correlation matrix among seed yield with $\mathrm{N}$ uptake and protein yield, and $\mathrm{N}$ uptake with protein yield of lentil.

\begin{tabular}{l|l|l|l|l}
\hline \multirow{2}{*}{ Characters } & \multicolumn{3}{c}{ Correlation coefficient (r value) } \\
\cline { 2 - 5 } & \multicolumn{2}{|c}{ N uptake } & \multicolumn{2}{c}{ Protein yield } \\
\cline { 2 - 5 } & $2004-05$ & $2005-06$ & $2004-05$ & $2005-06$ \\
\hline Seed yield & $0.996^{* *}$ & $0.988^{* *}$ & $0.996^{* *}$ & $0.997^{* *}$ \\
N uptake & - & - & $0.999^{* *}$ & $0.993^{* *}$ \\
\hline
\end{tabular}

** Significant at $1 \%$ level.

The overall results revealed that significant variation was observed in three varieties of lentil for nitrogen content, nitrogen uptake, protein content, and protein yield except $\mathrm{N}$ uptake and protein yield in 2005-06. Seeds collected from different sites of the plant had significant effect on nitrogen content and protein content. Seeds collected from lower parts $\left(\mathrm{P}_{3}\right)$ recorded the highest nitrogen content, nitrogen uptake, protein content, and protein yield. Seeds collected from lower parts of BARI Masur-4 and seeds collected from middle parts of BARI Masur-3 recorded higher $\mathrm{N}$ uptake and protein yield.

\section{References}

Abdul-Baki, A. A. and J E. Baker. 1973. Are changes in cellular organelles or membranes related to vigour loss in seeds. Seed Sci. and Technol. 1: 89-125.

Afzal, M. A., M A Bakr, A. Hamid, M. M. Haque and M. S. Aktar. 2003. Lentil in Bangladesh. Lentil, Blackgram and Mungbean Development Pilot Project, Pulses Research Station, BARI, Gazipur- 1701. Publication No. 24. pp. 27-31.

BARI. 2004. Annual Report, BARI, Joydebpur, Gazipur-1701, Bangladesh. pp. 1-413.

Bhuiyan, M. A. H. 2004. Evaluation of introducing mungbean into cereal based cropping pattern for sustainable soil fertility and productivity. Ph. D. Thesis. Department of Soil Sci. Bangladesh Agricultural Univ., Mymensingh, Bangladesh. pp. 1-217.

Delouche, J. C. 1973. Seed marturation. Seed Production Manual. NSC and Rockfeller Foundation. pp 162-165.

Dharmalingam, C. and R. N. Basu. 1990. Seed development and maturation in mungbean. Seed Res. 18(1): 1-6. 
Dharmalingam, C. and V. Ramakrishnan. 1978. Seed quality in relation to seed size and seed coat colour variation in blackgram ( Vigna radiata (L.) Hepper). Seed Res. 6: 101-109.

Dwivedi, B. S., M. Ram, B. P. Singh, M. Das and R. N. Prasad. 1990. Differential response of crops to boron fertilization in acid Alfisols. Indian J. Agric. Sc. 60(2): 122-127.

Harrington, J. F. 1972. Seed storage and longevity. In: Seed Biology, VII. (Kozlowski T T. ed.). Academic Press, New York. pp. 145-245.

Hossain, M. A., A. Hamid, K. A. Khaliq, M. A. Karim and M. M. Haque. 2004. Root growth and nitrogen uptake in mungbean (Vigna radiata) seedlings under suboptimal nitrogen environment. Bangladesh J. Soil Sc. 30(1\&2): 39-47.

Kumar, V., S. D. Shahidhan, M. B. Kurdikeri, A. S. Channaveeraswami and R. M. Hosmani. 2002. Influence of harvesting stages on seed yield and quality in paprika (Capsicum annuum L.). Seed Res. 30(1): 99-103.

Mahesha, C. R., A. S. Channaveeraswami, M. B. Kurdikeri, M. Shekhargouda and M. N. Merwade. 2001. Seed maturation studies in sunflower genotypes. Seed Res. 29(1): 95- 97.

Page, A. L., R. H. Miller and D. R. Keeney. 1982. Methods of Soil Analysis. Part 2.2 ${ }^{\text {nd }}$ Ed. Amer. Soc. Agron., Inc., Medison, Wisconsin, USA. pp. 595-624.

Quader, M. 1990. Growth, nodulation, nitrogen uptake and yield of chickpea varieties as influenced by Rhizobium strains. M Sc. (Ag.) Thesis. Dept. of Soil Sci., Bangladesh Agril. University, Mymensingh, Bangladesh. pp. 1-99.

Shahjahan, M. 2003. Storage effect on the nutritional quality of three major pulses. Ph. D. Thesis, Dept. of Biochem. and Molecular Biol., University of Dhaka, Bangladesh.

Tomar, S. K., P. Tripathi and A. L. Rajput. 2000. Effect of genotype, seeding method and diammonium phosphate on yield and protein and nutrient uptake by lentil (Lens culinaris). Indian J. Agron. 45(1): 148-152.

Yadav, S. K., S. Yadav, P. R. Kumar and K. Kant. 2005. A critical overview of chickpea seed technological research. Seed Res. 33(1): 1-15. 